\title{
Treatment of mesangiocapillary glomerulonephritis in children with combined immunosuppression and anticoagulation
}

\author{
S J CHAPMAN, J S CAMERON, C CHANTLER, AND D TURNER
}

Department of Paediatrics, Department of Renal Medicine, and Department of Pathology, Guy's Hospital, London

SUMMARY 10 children with mesangiocapillary (membranoproliferative) glomerulonephritis with features associated with a poor prognosis (either crescentic nephritis or a decline in renal function occurring after the initial presentation) were treated with a combination of immunosuppression and anticoagulation using corticosteroids, azathioprine, and heparin followed by warfarin and dipyridamole. Children were followed up for between 2 and 5 years, and at the end of this period 2 had died and 2 had entered the dialysis/transplant programme, but 6 were well ( 5 with glomerular filtration rates greater than $65 \mathrm{ml} / \mathrm{min}$ per $1.73 \mathrm{~m}^{2}$ ). We suggest that these results are sufficiently promising to encourage further trials of this form of treatment.

Mesangiocapillary glomerulonephritis (MCGN) (sometimes called membranoproliferative glomerulonephritis or MPGN) is a disease of childhood and early adult life. ${ }^{1}$ About $40 \%$ of patients with MCGN present with a nephrotic syndrome, the remainder with symptomless haematuria or proteinuria, or macroscopic haematuria and an acute nephritic syndrome. A depressed level of serum complement is generally found at some stage of the disease and this is often persistent, but some patients keep a normal serum complement throughout. The diagnosis is made by renal biopsy. The histological features are increased glomerular size, irregular thickening of the glomerular capillary walls, endocapillary proliferation, and an increase in the amount of mesangial matrix and the number of mesangial cells.

Two main histological subtypes are recognised: type I (or subendothelial deposit MCGN) in which the electron-dense deposits within the capillary wall are subendothelial, and an appearance of 'double contour' is seen in the capillary wall in silver-

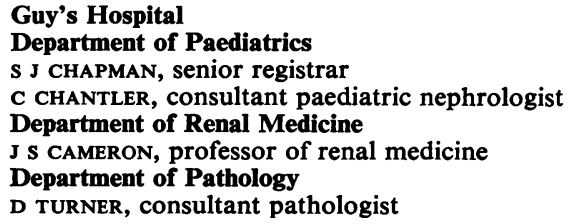

stained preparations; and type II MCGN (or intramembranous dense deposit disease) in which a continuous deposit is present within the basement membranes of glomerulus, tubule, and Bowman's capsule, and the 'double contour' appearance is not seen. Epithelial crescents may be seen in association with either type of MCGN, and are associated with a poor prognosis.

The clinical course of MCGN is usually protracted, with very few lesions healing completely, although patients can run a rapid course to early renal failure within a few months of diagnosis. In the series of Habib et al. ${ }^{2}$ comprising 105 children with both types of MCGN, the survival rate at 10 years was only $50 \%$, and the annual mortality was $6.4 \%$. In our series of 36 children with type I MCGN, ${ }^{1} 10$ year survival was $53 \%$. Features associated with a poor prognosis are listed in Table 1. Crescentic glomerulonephritis carried a very poor prognosis, with a mortality of $50 \%$ within one year and $100 \%$ within 4 years.

This prolonged and variable course makes the

Table 1 Features associated with a poor prognosis in mesangiocapillary glomerulonephritis (after Habib et al. ${ }^{2}$ )

Crescentic nephritis (more than $30 \%$ of glomeruli)

Deteriorating renal function after presentation

Persisting nephrotic syndrome

Macroscopic haematuria, especially if persistent

Raised blood urea at presentation (one-third of patients do badly)

Dense deposit disease (type II MCGN) 
assessment of the effects of treatment difficult. Because of the immunological pathogenesis of MCGN, corticosteroids and immunosuppressive agents have been used, alone and together. Results have been disappointing, and despite some encouraging reports of response to corticosteroids ${ }^{316}$ this has not always been confirmed ${ }^{2}$ nor was it confirmed in a controlled trial organised by the International Study of the Nephrotic Syndrome in Childhood. We have used a combination of immunosuppressive and anticoagulant drugs in patients with glomerulonephritis complicated by extensive crescent formation and declining renal function, which are known to carry a very poor prognosis. ${ }^{4-6}$ Some of these patients had MCGN with crescents, and these children are discussed here in more detail. Our results were encouraging and, together with the data of Kincaid-Smith ${ }^{7}$ using a similar regimen in adult nephrotic patients with MCGN and reduced renal function, suggested that combined immunosuppression and anticoagulation might be used in children with MCGN whose renal function was declining, but who did not necessarily show extensive crescent formation.

This paper presents preliminary results of treatment using combined immunosuppressive and anticoagulant treatment in a group of 10 children with MCGN and either extensive crescent formation or worsening renal failure, or both.

\section{Patients and treatment}

Patient selection. Each patient with MCGN was chosen for treatment because he had indicators that suggested a poor prognosis: either a decline in renal function during follow-up (glomerular filtration rate falling by at least $20 \mathrm{ml} / \mathrm{min}$ per $1 \cdot 73 \mathrm{~m}^{2}$, to less than $65 \mathrm{ml} / \mathrm{min}$ per $1.73 \mathrm{~m}^{2}$ ), or more than $50 \%$ of glomeruli in a renal biopsy with crescents. We also planned to treat any child with severely impaired renal function at presentation, as one-third of such patients do badly. All but one of such patients presenting during the period of study had more than $50 \%$ crescents, and were treated for this reason. One boy (who was withdrawn from the study when treatment had to be stopped because of appendicitis) had diminished renal function and only $10 \%$ of glomeruli affected by crescents. Details of the 10 children are given in Table 2.

The early course of Cases 1 and 3 was described by Brown et al.;4 data on glomerular filtration rate only of Cases $1,2,3$, and 4 were given in Table 1 of Cameron. ${ }^{6}$

Treatment. The quadruple therapy regimen of immunosuppression and anticoagulation consisted of: prednisone $2 \mathrm{mg} / \mathrm{kg}$ per $24 \mathrm{~h}$ decreasing to 0.25 $\mathrm{mg} / \mathrm{kg}$ per $24 \mathrm{~h}$ on alternate days, azathioprine 2 $\mathrm{mg} / \mathrm{kg}$ per $24 \mathrm{~h}$, subcutaneous heparin 4 times a day for one month to double the thrombin time, followed by warfarin to double the prothrombin time, and dipyridamole $10 \mathrm{mg} / \mathrm{kg}$ per $24 \mathrm{~h}$.

Full treatment was continued for one year, then one drug at a time was stopped, beginning with azathioprine in the first 4 patients. Six children were maintained longer on prednisone and azathioprine

Table 2 Patients treated with quadruple therapy

\begin{tabular}{|c|c|c|c|c|c|c|c|c|}
\hline Case & $\begin{array}{l}\text { Age } \\
\text { (years) }\end{array}$ & Sex & $\begin{array}{l}\text { Histological } \\
\text { type }\end{array}$ & $\%$ crescents & $\begin{array}{l}\text { Nephrotic } \\
\text { syndrome }\end{array}$ & $\begin{array}{l}\text { Macroscopic } \\
\text { haematuria }\end{array}$ & $\begin{array}{l}\text { Reasonfor } \\
\text { treatment }\end{array}$ & $\begin{array}{l}\text { Glomerular filtration rate } \\
\text { at start of treatment } \\
\left(\mathrm{ml} / \mathrm{min} \text { per } 1 \cdot 73 \mathrm{~m}^{2}\right)\end{array}$ \\
\hline $1^{*}$ & 6 & $\mathbf{F}$ & $\begin{array}{l}\text { Linear dense } \\
\text { (II) }\end{array}$ & 100 & - & + & $\begin{array}{l}\text { Crescentic } \\
\text { nephritis and anuria }\end{array}$ & $0 \dagger$ \\
\hline 2 & 12 & $\mathbf{M}$ & $\begin{array}{l}\text { Subendothelial } \\
\text { (I) }\end{array}$ & 50 & + & + & Crescentic nephritis & $37 \dagger$ \\
\hline $3^{*}$ & 7 & $\mathbf{F}$ & $\begin{array}{l}\text { Subendothelial } \\
\text { (I) }\end{array}$ & 50 & + & - & Crescentic nephritis & $22 \dagger$ \\
\hline 4 & 8 & $\mathbf{M}$ & $\begin{array}{l}\text { Subendothelial } \\
\text { (I) }\end{array}$ & 80 & + & - & $\begin{array}{l}\text { Crescentic nephritis } \\
\text { and anuria }\end{array}$ & ot \\
\hline 5 & 7 & $\mathbf{F}$ & $\begin{array}{l}\text { Linear dense } \\
\text { (II) }\end{array}$ & 85 & + & - & Crescentic nephritis & 55 \\
\hline 6 & 12 & $\mathbf{F}$ & $\begin{array}{l}\text { Subendothelial } \\
\text { (I) }\end{array}$ & 0 & + & + & $\begin{array}{l}\text { Deteriorating renal } \\
\text { function }\end{array}$ & 39 \\
\hline 7 & 12 & $\mathbf{F}$ & $\begin{array}{l}\text { Linear dense } \\
\text { (II) }\end{array}$ & 6 & + & + & $\begin{array}{l}\text { Deteriorating renal } \\
\text { function }\end{array}$ & 51 \\
\hline 8 & 11 & $\mathbf{F}$ & $\begin{array}{l}\text { Subendothelial } \\
\text { (I) }\end{array}$ & 0 & + & - & $\begin{array}{l}\text { Deteriorating renal } \\
\text { function }\end{array}$ & 60 \\
\hline 9 & 13 & $\mathbf{M}$ & $\begin{array}{l}\text { Subendothelial } \\
\text { (I) }\end{array}$ & 10 & - & + & $\begin{array}{l}\text { Deteriorating renal } \\
\text { function }\end{array}$ & 60 \\
\hline 10 & 10 & $\mathbf{M}$ & Linear dense & 0 & + & - & $\begin{array}{l}\text { Deteriorating renal } \\
\text { function }\end{array}$ & 38 \\
\hline
\end{tabular}

* Early course was described by Brown et al. 4 as Cases 6 and 5.

$\dagger$ Data on glomerular filtration rate are given in Table 1 of Cameron. 6 
after anticoagulants had been stopped at 12-18 months, because there was a rapid decline in renal function after withdrawal in some earlier patients (see below).

\section{Results}

Renal function. Table 3 gives details of the outcome in the 10 children treated for at least a year, or until terminal renal failure. Glomerular filtration rate was measured using a single injection of ${ }^{51} \mathrm{Cr}$-edetate. ${ }^{15}$ For the whole group, glomerular filtration rate rose from a pretreatment mean of $36 \mathrm{ml} / \mathrm{min}$ per $1.73 \mathrm{~m}^{2}$ to $56 \mathrm{ml} / \mathrm{min}$ per $1.73 \mathrm{~m}^{2}$ after one year. After a follow-up period of between 2 and 5 years (mean 3.25) 4 patients had died or had entered the dialysis/ transplant programme, and 6 were well. Five of these had glomerular filtration rates in excess of $65 \mathrm{ml} / \mathrm{min}$.

In the 5 children with crescentic nephritis (Cases 1 to 5), the mean glomerular filtration rate increased after a year's treatment from 23 to $50 \mathrm{ml} / \mathrm{min}$ per $1.73 \mathrm{~m}^{2}$. One child (Case 1), in renal failure and already on dialysis at the start of treatment, recovered no function. The changes in glomerular filtration rates for the other 4 are shown in Fig. 1. Case 2 had no apparent response, and declined slowly into chronic renal failure. He has now received a renal transplant. Case 3 showed initial improvement, but after withdrawal of azathioprine her renal function deteriorated sharply, and she died in renal failure $3 \frac{1}{2}$ years after starting quadruple therapy. In 2 children (Cases 4 and 5), one of whom was anuric at presentation, with more than $80 \%$ of glomeruli showing crescents, renal function returned to normal and is still normal 2 years later.

Cases 6 to 10 were treated because of a late decline in renal function; the mean glomerular filtration rate rose from 50 to $64 \mathrm{ml} / \mathrm{min}$ per $1 \cdot 73 \mathrm{~m}^{2}$ after a year's treatment, a rise of $14 \mathrm{ml} / \mathrm{min}$ per $1.73 \mathrm{~m}^{2}$, whereas in the year before treatment there had been a mean fall of $49 \mathrm{ml} / \mathrm{min}$ per $1 \cdot 73 \mathrm{~m}^{2}$.

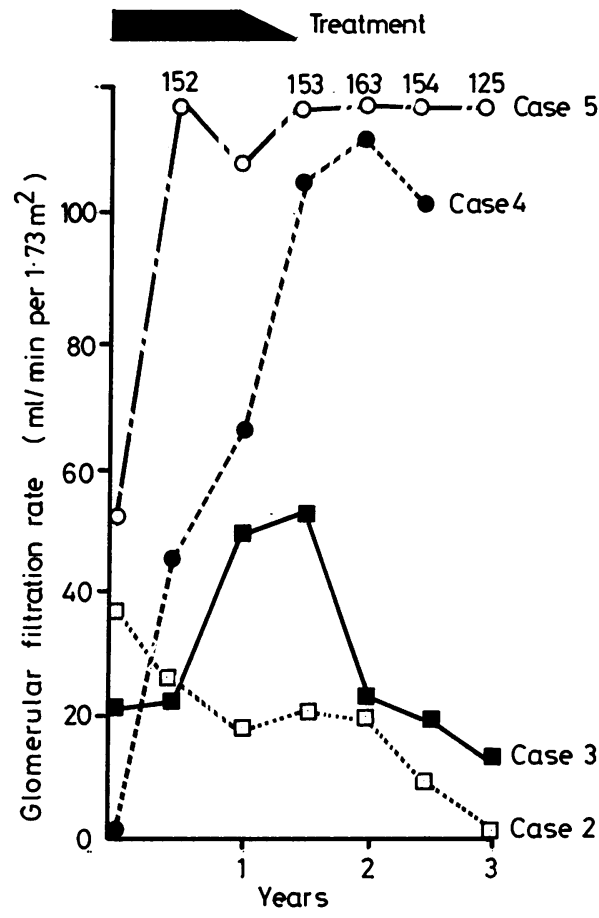

Fig. 1 Changes in glomerular filtration rate after treatment with immunosuppression and anticoagulation in patients with crescentic nephritis. Duration of treatment is shown (and in Figs 2 and 3) by the black bar at the top.

After follow-up from 2 to 5 years (mean 3.4) one child is on dialysis, but the other 4 are well with glomerular filtration rates of $38,66,72$, and 102 $\mathrm{ml} / \mathrm{min}$ per $1.73 \mathrm{~m}^{2}$. The condition of one child deteriorated after treatment was stopped and he is now on dialysis, and is discussed below; the changes in glomerular filtration rates for the other 4 are shown in Fig. 2. The child whose glomerular

Table 3 Progress of patients treated with quadruple therapy

\begin{tabular}{|c|c|c|c|c|c|c|}
\hline \multirow[t]{2}{*}{ Case } & \multirow[t]{2}{*}{ Reason for treatment } & \multicolumn{4}{|c|}{ Glomerular filtration rate ( $\mathrm{ml} / \mathrm{min}$ per $\left.1.73 \mathrm{~m}^{2}\right)$} & \multirow{2}{*}{$\begin{array}{l}\text { Length of follow-up } \\
\text { from start of } \\
\text { treatment (years) }\end{array}$} \\
\hline & & $\begin{array}{l}\text { One year } \\
\text { before treatment }\end{array}$ & $\begin{array}{l}\text { At start of } \\
\text { treatment }\end{array}$ & One year later & Present state & \\
\hline $\begin{array}{l}1 \\
2 \\
3 \\
4^{*} \\
5^{*} \\
6 \\
7^{*} \\
8^{*} \\
9 \\
10^{*}\end{array}$ & $\begin{array}{l}\text { Crescentic nephritis } \\
\text { Crescentic nephritis } \\
\text { Crescentic nephritis } \\
\text { Crescentic nephritis } \\
\text { Crescentic nephritis } \\
\text { Deteriorating renal function } \\
\text { Deteriorating renal function } \\
\text { Deteriorating renal function } \\
\text { Deteriorating renal function } \\
\text { Deteriorating renal function }\end{array}$ & $\begin{array}{r}70 \\
104 \\
106 \\
80 \\
134\end{array}$ & $\begin{array}{r}0 \\
37 \\
22 \\
0 \\
55 \\
39 \\
51 \\
60 \\
60 \\
38\end{array}$ & $\begin{array}{l}\text { Dead } \\
18 \\
49 \\
65 \\
106 \\
69 \\
84 \\
53 \\
54 \\
50\end{array}$ & $\begin{array}{l}\text { Dead } \\
\text { Renal transplant } \\
\text { Dead } \\
102 \\
125 \\
\text { Dialysis } \\
72 \\
38 \\
66 \\
102\end{array}$ & $\begin{array}{l}0 \cdot 5 \\
2 \cdot 5 \\
3 \cdot 5 \\
2 \cdot 5 \\
3 \cdot 25 \\
3 \cdot 5 \\
2 \cdot 25 \\
3 \cdot 0 \\
5 \cdot 75 \\
2 \cdot 75\end{array}$ \\
\hline
\end{tabular}

* Still on treatment at last follow-up. 


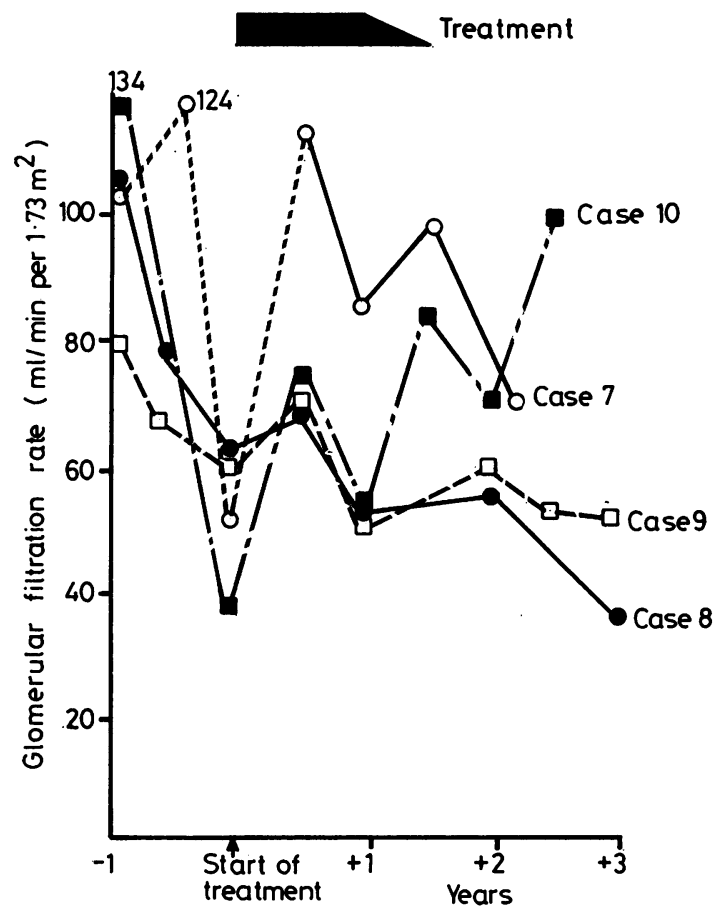

Fig. 2 Changes in glomerular filtration rate before and after treatment with immunosuppression and anticoagulation for declining renal function.

filtration rate is now $38 \mathrm{ml} / \mathrm{min}$ is known to have complied poorly with prescribed treatment.

Histology. Five of the 6 patients who have done well have had post-treatment biopsies, and the findings are summarised in Table 4. The extent of the deposits is difficult to judge, but was not thought to be less in any biopsy and was definitely worse in one. Epithelial crescents had resolved without an equivalent increase in glomerular sclerosis in 2 posttreatment biopsies, and cellularity had decreased in 3 .

Treatment withdrawal. Two children showed a marked decline in renal function associated in time with withdrawal of treatment, in one case after stop- ping azathioprine, and in the other after stopping anticoagulants, azathioprine and corticosteroids having already been stopped. The changes in glomerular filtration rate related to treatment are shown in Fig. 3. In neither case did reintroduction of treatment reverse the downwards trend.

Complications. Despite the potential toxicity of the treatment, there have been few complications in these patients. One boy was excluded from the series as treatment was stopped because of masked acute appendicitis. Cellulitis of the leg has been the only serious infective complication, although one boy had localised herpes zoster. One child failed to tolerate azathioprine because of gastrointestinal disturbance, and 6-mercaptopurine was eventually substituted.

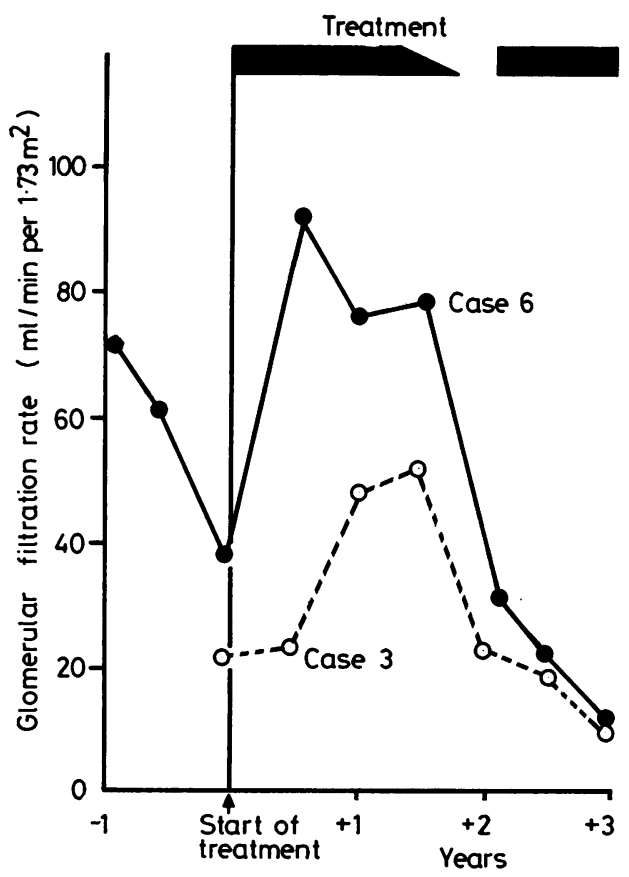

Fig. 3 Changes in glomerular filtration rate after withdrawal of treatment with immunosuppression and anticoagulation in 2 patients.

Table 4 Changes in histology after treatment

\begin{tabular}{rlllll}
\hline Case & $\%$ glomeruli with crescents & $\begin{array}{c}\text { \% sclerosed glomeruli } \\
\text { after treatment }\end{array}$ & Deposit & Cellularity \\
\cline { 2 - 5 } & Before treatment & After treatment & & No change & Decreased \\
\hline 4 & 80 & 0 & 34 & No change & Decreased \\
5 & 85 & 0 & 25 & Increased & No change \\
7 & 6 & 0 & 12 & No change & No change \\
9 & 10 & 0 & 14 & No change & Decreased \\
\hline
\end{tabular}


The most common complication has been failure to comply with the complicated regimen prescribed, which included hypotensive therapy and diuretics in 6 instances. This may be a reflection of the age group, as most of our patients were adolescents faced with the additional problems of a chronic illness. At least 3 were known to have taken their medications variably and unreliably, which is obviously a particular hazard if anticoagulant dosage is being adjusted according to prothrombin time.

\section{Discussion}

The difficulties of assessing treatment efficacy in a fairly rare disease with a variable individual course and an overall mortality of $50 \%$ at 10 years have already been mentioned. However, this small group of children were treated with combined anticoagulation and immunosuppression because findings suggested poor prognosis, and renal function has been maintained better than the natural history of the disease would predict. In the large French series $^{2}$ mortality for MCGN with more than $30 \%$ glomeruli showing crescents was $50 \%$ at one year and $100 \%$ at 4 years, whereas for our small treated series it was $20 \%$ at one year and $40 \%$ at 2 years. In the French series of 105 cases, only 2 patients in whom a late decline in renal function during follow-up was observed, recovered renal function, whereas all our treated children in this group with later renal failure improved their glomerular filtration rates during treatment. The histological changes are difficult to evaluate without data on changes in untreated patients, but crescents disappeared and cellularity decreased.

The regimen used is complicated, but may be defended from knowledge of the mediation of injury in glomerulonephritis. Antithrombin agents, such as heparin and warfarin, may prevent continued fibrin deposition within and around the glomeruli. Leakage of fibrin into the extraglomerular space appears to be the main cause of crescent formation in experimental glomerulonephritis, ${ }^{8}$ and although treatment of experimental glomerulonephritis with antithrombin agents has given inconsistent results, ${ }^{5}$ earlier defibrination with ancrod protects rabbits given anti-GBM antibody nephritis. ${ }^{8}$ Platelets may be involved in the mediation of injury in nephritis; they certainly facilitate immune complex localisation in the vasculature in animal models. ${ }^{9-10}$ In MCGN platelet turnover is accelerated ${ }^{10}$ and lowered intraplatelet serotonin levels are found. ${ }^{11}$

The justification for using immunosuppression as well as anticoagulation is that such a regimen blocks inflammation induced by a variety of mechan- isms, and that even if such treatments alone do not appear to have an effect, the blocking of most or all pathways leading to inflammation at the same time might achieve benefit not obtainable with any agent alone. Combined immunosuppression and anticoagulation was first used in a mixed group of 6 adult patients by Kincaid-Smith et al. ${ }^{12}$ The only previous application to children (apart from those included in our previous papers) ${ }^{4}{ }^{6}$ was that by Robson $e t$ al. ${ }^{13}$ who treated 6 children with crescentic glomerulonephritis (4 of whom had type II MCGN) with antithrombin agents, dipyridamole and azathioprine, for up to 2 years. All had evidence of continuing intravascular coagulation and were selected for that reason. In a brief follow-up (one year) all 6 responded clinically, with return of renal function to normal, and in 5 biopsied patients histological appearances in the glomeruli improved. It is more difficult to assess the outcome of the 8 children with probable MCGN treated by Herdman et al. ${ }^{14}$ with anticoagulants alone, but 4 may have shown benefit.

The reduction in glomerular filtration rate observed in 2 patients on withdrawal is further evidence that the treatment had modified the progress of the disease. It may be that the improvement apparently obtained is only temporary. Only longer follow-up will determine this, but even if all that can be achieved is a postponement of renal failure for a few years during which time physical and emotional growth can continue, this would still be of great value in an illness which is otherwise likely to inflict the rigours of a dialysis-transplant programme on an adolescent already disturbed by chronic illness.

\section{Addendum}

During a further year's follow-up, two patients (Cases 4 and 10) have shown sharp deteriorations in function, the former is now on regular haemodialysis, the latter has a glomerular filtration rate of $39 \mathrm{ml} /$ min. The other 4 patients continue as before, although Case 8 has lost further function.

\section{References}

1 Cameron J S. Mesangiocapillary glomerulonephritis. In: Strauss J, ed. The nephrotic syndrome. Pediatric nephrology. Vol. 5. New York: Garland Press, 1979: 153-84.

${ }^{2}$ Habib R, Kleinknecht C, Gubler M C, Levy M. Idiopathic membranoproliferative glomerulonephritis in children. Report of 105 cases. Clin Nephrol 1973; 1: 194-214.

3 McAdams A J, McEnery P T, West C D. Mesangiocapillary glomerulonephritis; changes in glomerular morphology with long-term alternate-day prednisone therapy. J Pediatr 1975; 86: 23-31.

- Brown C B, Turner D, Ogg C S, et al. Combined immunosuppression and anticoagulation in rapidly progressive glomerulonephritis. Lancet 1974; ii: 1166-72. 
5 Cameron J S. The treatment of glomerulonephritis with inhibitors of coagulation. In: Kluthe $R$, Batsford $S \mathbf{R}$, Vogt A, eds. Glomerulonephritis. Stuttgart: Thieme, 1977: 154-64.

6 Cameron J S. The treatment of severe glomerulonephritis with combined immunosuppression and anticoagulation. In: Bergeron M, ed. Proceedings of the VIIth International Congress of Nephrology, Montreal, June 1978. Basel: Karger, 1978: 419-24.

7 Kincaid-Smith P. The treatment of chronic mesangiocapillary (membranoproliferative) glomerulonephritis with impaired renal function. Med J Aust 1972; ii: 587-92.

8 Naish P, Penn G B, Evans D J, Peters D K. The effect of defibrination on nephrotoxic serum nephritis in rabbits. Clin Sci Mol Med 1972; 42: 643-6.

9 Cameron J S. Platelets and glomerulonephritis. Nephron $1977 ; 18$ : 253-8.

10 George C R P, Slichter S J, Quadracci L J, Striker G E, Harker L A. A kinetic evaluation of hemostasis in renal disease. N Engl J Med 1974; 291 : 1111-5.

11 Parbtani A, Cameron J S. Platelet and plasma serotonin in glomerulonephritis. I. Thromb Res 1979; 15: 109-25.

12 Kincaid-Smith P, Saker B M, Fairley K. Anticoagulants in 'irreversible' acute renal failure. Lancet 1968; ii: 1360-3.
13 Robson A M, Cole B R, Kienstra R A, Kissane J M, Alkjaersig N, Fletcher A P. Severe glomerulonephritis complicated by coagulopathy: treatment with anticoagulant and immunosuppressive drugs. J Pediatr 1977; 90: 881-92.

14 Herdman R C, Edson J R, Pickering R J, Fish A J, Marker M, Good R A. Anticoagulants in renal disease in children. Am J Dis Child 1970; 119: 27-35.

15 Chantler C, Garnett E S, Parsons V, Veall N. Glomerular filtration rate measurement in man by the single injection method using ${ }^{51} \mathrm{Cr}$-EDTA. Clin Sci 1969; 37: 169-80.

16 Cole B R, Brocklebank J T, Kienstra R A, Kissane J M, Robson A M. 'Pulse' methylprednisolone therapy in the treatment of severe glomerulonephritis. J Pediatr 1976; 88: $307-14$.

Correspondence to Dr S J Chapman, Department of Paediatrics, Guy's Hospital, St Thomas Street, London SE1 9RT.

Received 3 July 1979 